Biochimica et Biophysica Acta, 349 (1974) 402-414

(C) Elsevier Scientific Publishing Company, Amsterdam - Printed in The Netherlands

BBA 98002

\title{
ISOLATION AND PARTIAL CHARACTERIZATION OF DINOFLAGELLATE CHROMATIN*
}

\author{
P.J. RIZZO** and L.D. NOODÉN \\ Department of Botany, University of Michigan, Ann Arbor, Mich. 48104 (U.S.A.)
}

(Received November 9th, 1973)

\section{Summary}

Chromatin was prepared by two different methods from isolated nuclei of Gyrodinium cohnii (Cryptothecodinium cohnii) and Peridinium trochoideum. These isolation procedures are different from those generally used to prepare eukaryote chromatin, because the latter do not work for dinoflagellate chromatin. The chemical composition of this chromatin is similar for both methods of preparation and both organisms. Dinoflagellate chromatin contains DNA, RNA, acid-soluble and acid-insoluble protein as does chromatin from higher plants and animals, but the amount of acid-soluble protein relative to DNA $(0.02-0.08)$ is much lower than that of typical eukaryotes (about 1). Evidence is presented to show that proteolytic degradation is unlikely to account for the low acid-soluble protein content in dinoflagellate chromatin. Exclusion chromatography of the chromatin on large-pore gels (Bio Gel A-15m or Sephadex G-200) indicates that the bulk of the protein present in the chromatin preparations migrates with the DNA. $G$. cohnii and $P$. trochoideum chromatin show an ultraviolet absorption spectrum, which is intermediate between DNA and typical eukaryote chromatin, and this is not significantly changed by gel exclusion chromatography. Preliminary results suggest that the dinoflagellate DNA-associated proteins do not stabilize the DNA against melting. Chromatin prepared from log-phase cells has more protein and RNA than chromatin from stationary-phase cells. The chemical composition of dinoflagellate chromatin is compared with that of prokaryotes and eukaryotes.

Introduction

The chromosomes of the more advanced eukaryotes are much more com-

* Taken in part from a dissertation submitted by P.J.R. to the graduate school of the University of Michigan in partial fulfillment of the requirements for the Ph.D. degree.

** Present address: Horticulture Department, Purdue University, Lafayette, Ind. 47907 (U.S.A.) 
plex than those of prokaryotes. Since this large difference in complexity may represent the extremes of an evolutionary continuum [1], the chromosomes of primitive eukaryotes are of special interest as these organisms may represent transition forms between the two extremes [2]. Thus it is significant that the nuclear organization of the dinoflagellates seems to be intermediate between that of prokaryotes and eukaryotes [3-7]. In fact, a third kingdom, the Mesokaryota, has been proposed to include the dinoflagellates [8].

One of the most striking differences between the chromosomes of dinoflagellates and those of typical eukaryotes is that their chromosomes remain condensed through the entire cell cycle. Another difference is in the relative amount of protein. Cytochemical tests for basic amino acids in protein suggest that the dinoflagellate chromosome is devoid of basic protein $[3,4,9]$, such as histones, and furthermore, this can be interpreted to show that dinoflagellate chromosomes lack protein of any kind $[3,4,10]$. In contrast, a study using immunofluorescent techniques indicated that a DNA-histone complex is present in the chromosomes of dinoflagellates [11].

In order to resolve the question about the presence of histone or nonhistone proteins associated with the nuclear DNA of dinoflagellates in the present study, chromatin was prepared from isolated nuclei of two dinoflagellates by two different methods. It was found that the chromatin from Gyrodinium cohnii (Cryptothecodinium cohnii) and Peridinium trochoideum contains some protein, but only a very small portion of this protein is acid-soluble, as are histones, and even the acid-insoluble protein content is less than that of typical eukaryotes. Clearly, the chromatin of these dinoflagellates is very different from that of typical eukaryotes, and different techniques are required to prepare it. A preliminary report of this work has been published [12]

\section{Materials and Methods}

\section{Culture conditions and isolation of nuclei}

As described for G. cohnii (C. cohnii) and P. trochoideum by Rizzo and Noodén [13]. These two species are quite different; for example the former is not photosynthetic whereas the latter is.

The term "log phase" is used here to designate rapidly growing cultures, which have not yet reached maximum cell density. Since a given inoculum reaches maximum cell density in a predictable period of time under our highly controlled conditions, the length of the incubation period can be used to estimate the growth phase of the cells. The term "stationary phase" is used here to designate cultures which have stopped dividing, and this can be judged from the incubation time as described above or visually. Under the set of culture conditions employed for G. cohnii, for example, log-phase cells were harvested 3.5 days after inoculation. Stationary phase cells were allowed to grow 6-7 days before harvesting. Difficulty in isolating the nuclei prevented a larger temporal separation of $\log$ and stationary phase cells. If the cells were harvested too soon, large amounts of "starch" prevented the isolation of clean nuclei. On the other hand, if the cells were allowed to grow for longer than 7 days, very few intact nuclei were recovered due mainly to poor cell disruption resulting from thickening of the cell walls. 


\section{Preparation of chromatin-calcium method}

This is a modification of the method used by Towill and Noodén [14] for isolation of higher plant chromatin. Purified nuclei were washed twice by suspending them in $5-8 \mathrm{ml}$ of buffer containing $0.14 \mathrm{M} \mathrm{NaCl}, 5 \mathrm{mM} \mathrm{MgCl}, 10$ $\mathrm{mM}$ Tris $(\mathrm{pH} \mathrm{7.6)}$ and centrifuging at $12000 \times \mathrm{g}$ for $10 \mathrm{~min}$. All operations were carried out at $0-4^{\circ} \mathrm{C}$. The resulting pellet of washed nuclei was then suspended in $7 \mathrm{ml}$ of buffer containing $10 \mathrm{mM}$ Tris, $1 \mathrm{mM}$ EDTA (pH 8.0) and sonicated for $3 \mathrm{~s}$ at $20000 \mathrm{~Hz}$ and maximum output with a Branson S-75 sonifier. The sonicate was then centrifuged at $12000 \times \mathrm{g}$ for $10 \mathrm{~min}$ (centrifugation at $25000 \times g$ for 15 min gave the same results).

The pellet was resuspended in $3 \mathrm{ml}$ of the Tris-EDTA buffer, and the previous centrifugation was repeated. The supernatants were combined, made $10 \mathrm{mM}$ in $\mathrm{CaCl}_{2}$ by adding solid $\mathrm{CaCl}_{2}$ [15], allowed to stand $15 \mathrm{~min}$, and then centrifuged at $12000 \times \mathrm{g}$ for $15 \mathrm{~min}$. The supernatant was discarded. The chromatin pellet was suspended in $5 \mathrm{ml}$ of $0.14 \mathrm{M} \mathrm{NaCl}-5 \mathrm{mM} \mathrm{MgCl}{ }_{2}-10 \mathrm{mM}$ Tris ( $\mathrm{pH} 7.6)$ and centrifuged at $12000 \times \mathrm{g}$ for $10 \mathrm{~min}$. The resulting pellet, containing about $80 \%$ of the DNA present in the nuclei, constituted the purified chromatin.

\section{Preparation of chromatin-2 $\mathrm{M} \mathrm{NaCl}$ method}

This method is similar to that outlined by Hnilica [16]. Purified nuclei were washed twice by suspending them in 5-8 $\mathrm{ml}$ of buffer containing $0.14 \mathrm{M}$ $\mathrm{NaCl}, 5 \mathrm{mM} \mathrm{MgCl}_{2}$ and $10 \mathrm{mM}$ Tris $(\mathrm{pH} \mathrm{7.6)}$ and centrifuging at $12000 \times \mathrm{g}$ for $10 \mathrm{~min}$. All operations were carried out at $0-4^{\circ} \mathrm{C}$. The resulting pellet of washed nuclei was suspended in $10-12 \mathrm{ml}$ of $2 \mathrm{M} \mathrm{NaCl}-10 \mathrm{mM}$ Tris (pH 8.0$)$ and stirred overnight. The preparation was then centrifuged at $12000 \times g$ for $15 \mathrm{~min}$, and the supernatant, which contained about $95 \%$ of the DNA present in the nuclei, was removed with a pasteur pipet. The chromatin was precipitated with 1 vol. of $40 \%$ trichloroacetic acid overnight and then centrifuged at $25000 \times \mathrm{g}$ for $15 \mathrm{~min}$. The chromatin pellet was washed twice with $80 \%$ ethanol. For chemical determinations, the $2 \mathrm{M} \mathrm{NaCl}$ supernatant was divided into 2 portions at the stage immediately preceding the addition of $40 \%$ trichloroacetic acid. One portion was used for the determination of DNA and RNA and the other for protein.

\section{Chemical determinations}

DNA and RNA were extracted by the method Ogur and Rosen [17]. DNA was determined by the diphenylamine reaction of Burton [18], RNA by the orcinol test [19] and protein by the method of Lowry et al. [20]. Calf thymus or salmon sperm DNA, purified yeast RNA and bovine serum albumin were used as standards. For the determination of protein, all samples (including the standard) were dissolved by heating at $80^{\circ} \mathrm{C}$ for $10 \mathrm{~min}$ in $0.5 \mathrm{M}$ or $1.0 \mathrm{M}$ $\mathrm{NaOH}$.

\section{Extraction of acid-soluble proteins}

Nuclei were suspended in $1-2 \mathrm{ml}$ of $0.25 \mathrm{M} \mathrm{HCl}$ or $0.125 \mathrm{M} \mathrm{H}_{2} \mathrm{SO}_{4}$ and extracted for $20 \mathrm{~min}$ with intermittant shaking. These suspensions were centrifuged in a Sorvall SS-34 rotor, at $25000 \times \mathrm{g}$ for $15 \mathrm{~min}$. The pellets pro- 
duced were extracted again as described above. The combined supernatants were centrifuged again to remove the small amounts of particulate material that occasionally break away from the $25000 \times \mathrm{g}$ pellet upon removal of the supernatant. The acid-soluble proteins were precipitated overnight with either 1 vol. of $40 \%$ trichloroacetic acid at $4^{\circ} \mathrm{C}$ or 8 vol. of acetone at $-15^{\circ} \mathrm{C}$. In both cases, the precipitates were collected by centrifugation at $25000 \times \mathrm{g}$ for $30 \mathrm{~min}$ in a Sorvall SS-34 rotor. The acid precipitates were washed twice with $3-5 \mathrm{ml}$ of $80 \%$ ethanol. The acetone precipitates were dried in a desiccator under a partial vacuum.

\section{Gel filtration chromatography,}

The chromatin used was prepared according to the calcium method through the step immediately before the addition of solid $\mathrm{CaCl}_{2}$. In order to keep the volume small, the $3 \mathrm{ml}$ wash with Tris-EDTA was also omitted. A total volume of $7 \mathrm{ml}$ was applied to a Biogel A-15m (molecular weight exclusion $15 \cdot 10^{6}$ ) or Sephadex G-200 (molecular weight exclusion $2 \cdot 10^{5}$ ) column pre-equilibrated with $10 \mathrm{mM}$ Tris $-1 \mathrm{mM}$ EDTA (pH 8.0). The column dimensions were $25-30 \mathrm{~cm} \times 2.4 \mathrm{~cm}$, and 3-4 ml fractions were collected. The DNA content of the fractions was determined by absorption at $260 \mathrm{~nm}$, and the protein content of the fractions was determined by the method of Lowry et al. [20]. Absorption spectra of the chromatin solutions were determined by checking absorbance at $1 \mathrm{~nm}$ intervals before and after passage through the column.

\section{Temperature melting studies}

Purified DNA was prepared from pelleted calcium chromatin by the method of Marmur [21] as described by Stern [22] for plant tissues, except that the pronase incubation step (pronase $B$, Calbiochem) was performed at $37^{\circ} \mathrm{C}$. The samples of DNA or chromatin were dissolved in $0.15 \mathrm{M} \mathrm{NaCl}-0.015$ $\mathrm{M}$ sodium citrate, $\mathrm{pH} 7.0$, and dialysed against several hundred volumes of $0.015 \mathrm{M} \mathrm{NaCl}-0.0015 \mathrm{M}$ sodium citrate overnight in the cold with three changes. The $A_{260 \mathrm{~nm}}$ of the samples was adjusted to about 0.5 (approximately $20 \mu \mathrm{g}$ DNA) with the dialysing buffer, and the samples were placed in cuvettes in a Beckman spectrophotometer. The temperature of the cuvette containing dialysing buffer only was monitored by a thermistor probe inserted into the cuvette. The absorbance at $260 \mathrm{~nm}$ was read for all cuvettes at $1^{\circ} \mathrm{C}$ intervals during the critical portion of the melting curve. In one experiment, $0.25 \mathrm{mM}$ EDTA (pH 8.0) was used as the solvent.

\section{Results}

\section{Preparation of chromatin}

When the dinoflagellate nuclei are ruptured in the low ionic strength Tris-EDTA medium, the chromosomes are dispersed; the chromatin does not form a gel as does the chromatin from most higher eukaryotes. Because the most common procedures for chromatin isolation depend on formation of a gel at low ionic strength, it was necessary to work out other procedures to isolate the DNA and DNA-associated proteins from dinoflagellates. The first involves 
breaking the $0.14 \mathrm{M} \mathrm{NaCl}$ washed nuclei and releasing the chromatin in a soluble state. Heavy debris such as nucleoli, nuclear membrane fragments, cell walls, starch grains and unbroken nuclei are then centrifuged out. The heavy debris pellet also contains $10-15 \%$ of the cells' DNA depending on the efficiency of nuclear breakage. EDTA was included to aid in nuclear disruption and has been used in the extraction of chromatin from isolated nuclei by others [23-25]. The chromatin extracted in this manner was found extremely difficult to pellet by centrifugation. For example, centrifugation at $269000 \times \mathrm{g}$ for $2 \mathrm{~h}$ pelleted only $23 \%$ of the DNA present and centrifugation at $122000 \times \mathrm{g}$ for $12-16 \mathrm{~h}$ pelleted $38-51 \%$ of the DNA present.

Since a large percentage of the chromatin could not be pelleted by centrifugation from the Tris-EDTA solutions, attempts were made to precipitate the chromatin from this solution by adding an excess of divalent cations. The procedure of Bhagavan and Atchley [26] which used $20 \mathrm{mM} \mathrm{MgCl}_{2}$ and $\mathrm{pH} 6.5$ to precipitate the deoxyribonucleoprotein from Bacillus subtilis enabled $80-90 \%$ of the DNA to be centrifuged out at $12000 \times g$ for $10 \mathrm{~min}$. Alternatively, the bulk of the DNA present could be pelleted at $12000 \times \mathrm{g}$ for 10 min if the chromatin solution was adjusted to $10 \mathrm{mM}$ in $\mathrm{CaCl}_{2}$ with solid $\mathrm{CaCl}_{2}$ as described by Frenster et al. [15]. This latter procedure was adopted, because it kept the volume small. The chromatin pellet was washed once with 0.14 $\mathrm{NaCl}-10 \mathrm{mM}$ Tris - $5 \mathrm{mM} \mathrm{MgCl}_{2}$ (pH 7.6) to remove any loosely bound protein and RNA that may have co-precipitated with the chromatin $[16,27]$. This chromatin will be referred to in the present study as "calcium chromatin". Relative to the DNA present in the nuclei, the yield is $75-85 \%$.

In the second method of chromatin preparation, the chromatin is extracted from washed nuclei by stirring overnight in $2 \mathrm{M} \mathrm{NaCl}$ and then precipitated with $20 \%$ trichloroacetic acid. Washes with $80 \%$ ethanol are included to remove the trichloroacetic acid, which could otherwise interfere with ultraviolet estimates and colorimetric determinations [28]. Chromatin prepared by this method will be designated as " $2 \mathrm{M} \mathrm{NaCl}$ chromatin" in the present study even though the DNA and the proteins are dissociated. The yield is $93-95 \%$ of the DNA present in the nuclei.

\section{Chemical composition of dinoflagellate chromatin}

The chemical composition of chromatin from isolated nuclei of $G$. cohnii and $P$. trochoideum is shown in Table I and II, respectively. Comparing the ratios of RNA or protein to DNA for chromatin and nuclei, it can be seen that the chromatin contains only half of the protein from the nuclei and even less, $10-30 \%$, of the RNA.

The relative amounts of DNA, RNA, acid-insoluble and acid-soluble protein depend on the growth phase of the cells at the time of harvest (Table I). With both methods, chromatin prepared from log-phase cells has considerably more RNA, acid-insoluble and acid-soluble protein relative to DNA than chromatin prepared from stationary phase cells. Table I also shows that in almost all instances the protein and especially the RNA and acid-soluble protein contents are higher for calcium chromatin than for the equivalent $2 \mathrm{M}$ $\mathrm{NaCl}$ chromatin.

Table II shows the chemical composition of calcium chromatin from log- 
TABLE I

CHEMICAL COMPOSITION OF NUCLEI AND CHROMATIN FROM G. COHNII

\begin{tabular}{|c|c|c|c|c|c|}
\hline Preparation & Method & $\begin{array}{l}\text { RNA /DNA } \\
\text { ratio }(w / w)\end{array}$ & $\begin{array}{l}\text { Acid- } \\
\text { insoluble } \\
\text { protein/DNA } \\
\text { ratio }(w / w)\end{array}$ & $\begin{array}{l}\text { Acid- } \\
\text { soluble } \\
\text { protein/DNA } \\
\text { ratio }(w / w)\end{array}$ & $\begin{array}{l}\text { Total } \\
\text { protein/DNA } \\
\text { ratio }(w / w)\end{array}$ \\
\hline Nuclei, log phase & & 0.32 & 0.99 & 0.13 & 1.12 \\
\hline Chromatin, log phase & Calcium & $0.094 \pm 0.004^{*}$ & $0.485 \pm 0.019$ & $0.075 \pm 0.005$ & $0.561 \pm 0.019$ \\
\hline Chromatin, log phase & $2 \mathrm{M} \mathrm{NaCl}$ & $0.041 \pm 0.001$ & $0.451 \pm 0.025$ & $0.028 \pm 0.001$ & $0.487 \pm 0.025$ \\
\hline Chromatin, stationary phase & Calcium & $0.049 \pm 0.003$ & $0.241 \pm 0.039$ & $0.059 \pm 0.009$ & $0.300 \pm 0.034$ \\
\hline Chromatin, stationary phase & $2 \mathrm{M} \mathrm{NaCl}$ & $0.029 \pm 0.002$ & $0.268 \pm 0.051$ & $0.019 \pm 0.002$ & $0.287 \pm 0.053$ \\
\hline
\end{tabular}

* Standard error.

phase cells and $2 \mathrm{M} \mathrm{NaCl}$ chromatin from stationary phase of a very different dinoflagellate, $P$. trochoideum. Comparing Tables I and II, one can see that the chemical composition of chromatin from the two dinoflagellates is quite similar.

Since histones (acid soluble) may be degraded by proteases, dinoflagellate nuclei and thence chromatin were prepared in the presence of known inhibitors of proteolysis [29]. The relative amount of acid-soluble protein does not change significantly when chromatin was prepared in the presence of proteolytic enzyme inhibitors phenylmethylsulfonylfluoride or sodium bisulfite (Table III).

\section{Gel filtration chromatography of dinoflagellate chromatin}

Fig. 1 shows the behavior of $G$. cohnii chromatin (prepared by the calcium method but applied to the column just before precipitation with $\mathrm{CaCl}_{2}$ ) in a Bio Gel A-15 m column (molecular weight exclusion $15 \cdot 10^{6}$ ). As can be seen from the figure, the bulk of the protein present in the chromatin preparation migrates with the DNA. Since the DNA runs in the exclusion volume with little or no tailing, the DNA has a high molecular weight, above $15 \cdot 10^{6}$. Chromatography of G. cohnii chromatin was also performed using Sephadex G-200 instead of Bio Gel A-15m, and the elution profile was very similar to

TABLE II

CHEMICAL COMPOSITION OF NUCLEI AND CHROMATIN FROM P. TROCHOIDEUM

\begin{tabular}{|c|c|c|c|c|c|}
\hline Preparation & Method & $\begin{array}{l}\text { RNA/DNA } \\
\text { ratio }(w / w)\end{array}$ & $\begin{array}{l}\text { Acid- } \\
\text { insoluble } \\
\text { protein } / \text { DNA } \\
\text { ratio }(w / w)\end{array}$ & $\begin{array}{l}\text { Acid- } \\
\text { soluble } \\
\text { protein } / D N A \\
\text { ratio }(w / w)\end{array}$ & $\begin{array}{l}\text { Total } \\
\text { protein } / D N A \\
\text { ratio }(w / w)\end{array}$ \\
\hline $\begin{array}{l}\text { Nuclei, log phase } \\
\text { Chromatin, log phase } \\
\text { Chromatin, stationary phase }\end{array}$ & $\begin{array}{l}\text { Calcium } \\
2 \mathrm{M} \mathrm{NaCl}\end{array}$ & $\begin{array}{l}0.22 \\
0.060 \pm 0.004^{*} \\
0.029 \pm 0.004\end{array}$ & $\begin{array}{l}1.22 \\
0.502 \pm 0.008 \\
0.209 \pm 0.028\end{array}$ & $\begin{array}{l}0.08 \\
0.056 \pm 0.008 \\
0.022 \pm 0.002\end{array}$ & $\begin{array}{l}1.30 \\
0.558 \pm 0.009 \\
0.230 \pm 0.027\end{array}$ \\
\hline
\end{tabular}

* Standard error. 


\section{TABLE III}

EFFECT OF INHIBITORS OF PROTEOLYTIC ENZYMES ON THE CHEMICAL COMPOSITION OF G. COHNII CHROMATIN

In these tests, the sodium bisulfite was included in all solutions used for the preparation of nuclei and chromatin except the $2.2 \mathrm{M}$ sucrose solution. This omission was necessary, because a precipitate formed when bisulfite and Triton X-100 were both present in the $2.2 \mathrm{M}$ sucrose. Phenylmethylsulfonylfluoride (PMSF) was included in the isolation medium and all the solutions used during the preparation of chromatin.

\begin{tabular}{llllll}
\hline Inhibitor & Preparation & $\begin{array}{l}\text { RNA/DNA } \\
\text { ratio }(w / w)\end{array}$ & $\begin{array}{l}\text { Acid- } \\
\text { insoluble } \\
\text { protein/DNA } \\
\text { ratio }(w / w)\end{array}$ & $\begin{array}{l}\text { Acid- } \\
\text { soluble } \\
\text { protein/DNA } \\
\text { ratio }(w / w)\end{array}$ & $\begin{array}{l}\text { Total } \\
\text { protein/DNA } \\
\text { ratio }(w / w)\end{array}$ \\
\hline None & $\begin{array}{l}\text { Chromatin } \\
\text { log phase } \\
\text { (calcium method) }\end{array}$ & 0.094 & 0.485 & 0.075 & 0.561 \\
NaHSO $3(5 \mathrm{mM}) \begin{array}{l}\text { Chromatin } \\
\text { log phase } \\
\text { (calcium method) } \\
\text { Chromatin } \\
\text { stationary phase } \\
\text { (2 M NaCl method) }\end{array}$ & 0.124 & 0.492 & 0.095 & 0.587 \\
PMSF (25 $\mu \mathrm{M})$ & $\begin{array}{l}\text { Chromatin } \\
\text { stationary phase } \\
\text { (2 M NaCl method) }\end{array}$ & 0.025 & 0.269 & 0.019 & 0.287 \\
\hline
\end{tabular}

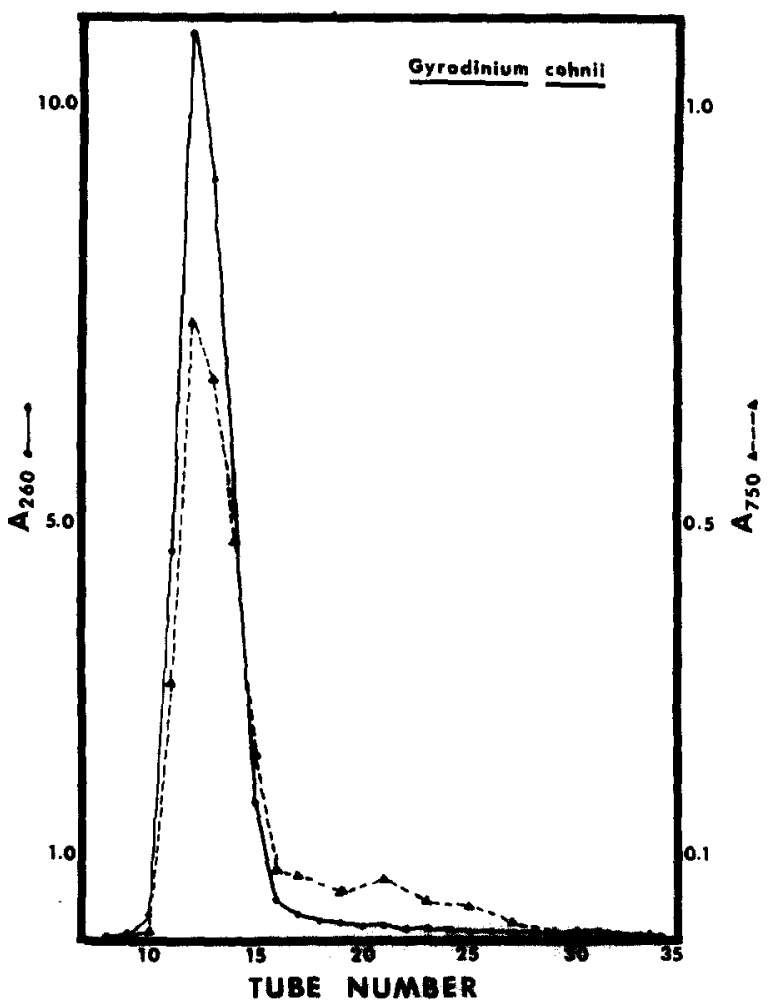

Fig. 1. Chromatography of $G$. cohnii chromatin on a Bio Gel A-1 $5 \mathrm{~m}$ column. The sample was eluted with $10 \mathrm{mM}$ Tris-1 mM EDTA (pH 8.0). DNA was estimated by absorption at $260 \mathrm{~nm}$, protein by the Lowry method. 
that shown in Fig. 1 as was the elution profile of $P$. trochoideum chromatin in Bio Gel A-15m column.

The protein and DNA peaks in Fig. 1 were cut out and weighed to give an estimate of the protein/DNA ratio based on the Lowry method for protein determination and absorption at $260 \mathrm{~nm}$ for DNA. The ratios obtained by this method were 0.78 for $G$. cohnii and 0.67 for $P$. trochoideum, which are a bit higher than the ratios obtained by direct chemical determinations (see Tables I and II).

The absorption spectra of the chromatin peak in $10 \mathrm{mM}$ Tris $-1 \mathrm{mM}$ EDTA ( $\mathrm{pH} \mathrm{8.0),} \mathrm{before} \mathrm{and} \mathrm{after} \mathrm{chromatography} \mathrm{are} \mathrm{shown} \mathrm{in} \mathrm{Fig.} \mathrm{2.} \mathrm{Passage}$ through the column alters the shape of the spectrum only slightly; the major change being less absorption in the trough region $(230-240 \mathrm{~nm})$. This is most likely due to a difference in turbidity, but it could also be due to removal of some low molecular weight compounds. However, the absorption spectra for $G$. cohnii and $P$. trochoideum both before and after chromatography are similar, but not identical, to typical chromatin preparations [30], showing little absorption at $320 \mathrm{~nm}$ with a peak at about $260 \mathrm{~nm}$, a trough at about $240 \mathrm{~nm}$, and a ratio of $A_{280 \mathrm{~nm}} / A_{260 \mathrm{~nm}}$ of about 0.6. The ratio $A_{230 \mathrm{~nm}} / A_{260 \mathrm{~nm}}$ is about 0.6 , which is a bit lower than typical chromatin $(0.7-1.0)$ and may reflect the lower protein content of dinoglagellate chromatin. Thus dinoflagellate chromatin is Intermediate between DNA and typical eukarvote chromatin in its ultraviolet absorption.

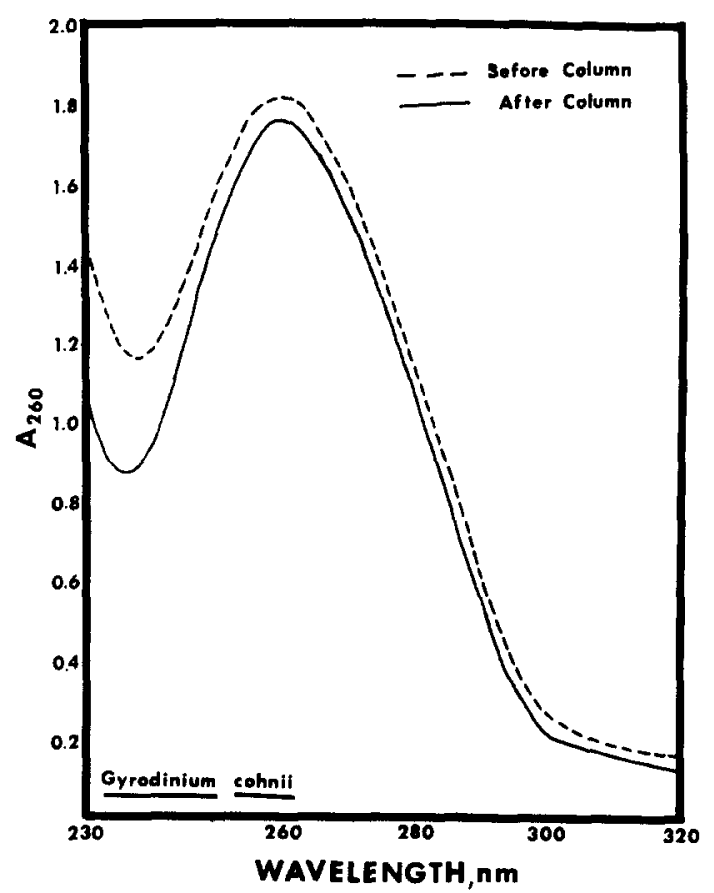

Fig. 2. Ultraviolet absorption spectra of $G$. cohnii chromatin before and after Bio Gel A-15m column chromatography. 


\section{Melting of DNA and chromatin}

Preliminary experiments were done to see if the DNA-associated proteins of dinoflagellates could stabilize the DNA against melting (increase the $T_{\mathrm{m}}$ ). The $T_{\mathrm{m}}$ values in $0.015 \mathrm{M} \mathrm{NaCl}-0.0015 \mathrm{M}$ sodium citrate were approximately 67,64 and $66^{\circ} \mathrm{C}$ for $G$. cohnii DNA, whole chromatin (prepared by the calcium method) and acid-extracted chromatin, respectively, and the melting profiles were indistinguishable. Using $2.5 \cdot 10^{-4} \mathrm{M}$ EDTA as the solvent, G. cohnii DNA and chromatin had a $T_{m}$ of about $47^{\circ} \mathrm{C}$.

\section{Discussion}

\section{DNA-associated proteins in dinoflagellates}

Although the earlier cytochemical studies have suggested that the dinoflagellate chromosome is devoid of protein $[3,4,10]$ the present study has shown that dinoflagellate chromatin contains a small amount of acid-soluble protein and a considerable amount of acid-insoluble protein. From the probable role that chromosomal proteins play in the regulation of gene activity and the maintenance of chromosome structure in other eukaryotes $[1,2]$ the presence of DNA-associated proteins would be expected. Indeed, their absence would be surprising. Moreover, Franker [31] has recently reported DNAbinding proteins in $C$. cohnii ( $G$. cohnii). Why then, have cytochemical tests failed to detect the presence of protein in dinoflagellate chromosomes? It is possible that the amount of protein is too low and the staining levels are too close to the background to be detected by these methods.

\section{Calcium chromatin versus $2 \mathrm{M} \mathrm{NaCl}$ chromatin}

Since dinoflagellate chromatin does not form a gel which is readily centrifuged from low ionic strength solutions, the standard procedures $[23,30]$ for chromatin isolation do not work, and other techniques had to be developed. The two different methods of chromatin isolation used in the present study produced chromatins with similar but not identical compositions. In general, chromatin prepared by the calcium method contained a higher proportion of RNA and acid-soluble protein. This suggests ribosomal contamination; however, this is considered unlikely, because the nuclei were washed with $0.14 \mathrm{M}$ $\mathrm{NaCl}$ to remove nuclear sap proteins and nuclear ribosomes [16,27]. Furthermore, if any free ribosomes were present, they would be extracted with $2 \mathrm{M}$ $\mathrm{NaCl}$ and thus should also be present in the $2 \mathrm{M} \mathrm{NaCl}$ chromatin.

Since the nuclear membranes and nucleoli are insoluble in $1-2 \mathrm{M} \mathrm{NaCl}$ [27,32-36], the nuclear proteins which are not removed with $0.14 \mathrm{M} \mathrm{NaCl}$ but are solubilized by $2 \mathrm{M} \mathrm{NaCl}$ are probably not nucleolar or nuclear membrane proteins. Although there is a difference in the acid-soluble protein/DNA ratios of the chromatins prepared by the two methods, electrophoresis in ureaacrylamide gels at $\mathrm{pH} 3.2$ shows banding patterns which are quite similar [37]. This similarity would not be expected if the quantitative differences in the acid-soluble proteins stemmed from nuclear membrane or nucleolar protein contamination in the calcium chromatin. Thus we are at present unable to account for the quantitative differences in acid-soluble protein between the calcium and the $2 \mathrm{M} \mathrm{NaCl}$ chromatin. Other explanations such as interference 
with the Lowry determination [38] or the RNA measurement [28,39] cannot be ruled out especially in the case of acid-soluble protein which is present in very small amounts and therefore more affected by interference. Even though there are small quantitative differences in the RNA and acid-soluble protein content, the two chromatin preparations are very similar in their total protein content and the protein gel electrophoretic patterns [37] which suggests that the two methods produce very similar chromatin preparations.

Since the acid-soluble protein (and therefore histone) content is very low and chromatin aggregation is known to be dependent on histones [40], the absence (or paucity) of histones explains why the dinoflagellate chromatin does not aggregate in low ionic strength solutions and why the standard procedures for chromatin isolation did not work.

\section{How representative is the isolated dinoflagellate chromatin?}

As with chromatin prepared from any organism, there is always a question about the inclusion of components that were not present in vivo or the removal of components that were present in vivo. In order to minimize cytoplasmic contamination, chromatin was prepared from isolated nuclei rather than directly from whole cells. In addition, chromosomal material is also less likely to be lost from the intact nucleus. Thus the addition or removal of material is largely limited to the steps going from nuclei to chromatin. The fact that the composition of dinoflagellate chromatin is quite similar when prepared by two different methods indicates that no gross changes occurred during preparation from the nuclei.

Experiments with inhibitors of proteolytic enzymes indicate that the low protein/DNA ratio, in particular the low acid-soluble protein/DNA ratio, is not due to proteolysis such as the degradation of histones from rat liver [29]. In addition, the acid-soluble protein content of the nuclei is also low, and these are isolated quickly enough that the effect of proteolytic enzymes should be minimal. The fact that the purified nuclei were used as starting material greatly lessens the chance of contamination due to cytoplasmic matter, and the centrifugation following nuclear rupture should remove the larger particles. Furthermore, the low RNA/DNA ratios also indicate that ribosomal contamination is at most very small. On the other hand, the movement of almost all of these proteins with the DNA on large-pore exclusion gels suggests that they are associated with the DNA. Finally, the low protein contents reported here are consistent with the histochemical observations which show that dinoflagellate chromosomes have a low protein content relative to typical eukaryote chromosomes [9].

The values given for $P$. trochoideum chromatin compare quite well with the corresponding chromatin from $G$. cohnii suggesting that data are representative for all dinoflagellate chromatin.

\section{Chromatin from stationary and log-phase cultures}

Since the transcriptional activity can be expected to differ in dividing and nondividing cells, it is of interest to compare the chromatin from these cells. The more active cells (dividing) contain not only more RNA but also more protein, both acid soluble and acid insoluble. This is in agreement with other 


\begin{tabular}{|c|c|c|c|c|}
\hline Source of chromatin & $\begin{array}{l}\text { RNA/DNA } \\
\text { ratio }(w / w)\end{array}$ & $\begin{array}{l}\text { Acid- } \\
\text { soluble } \\
\text { protein/DNA } \\
\text { ratio }(w / w)\end{array}$ & $\begin{array}{l}\text { Acid- } \\
\text { insoluble } \\
\text { protein/DNA } \\
\text { ratio }(w / w)\end{array}$ & Reference \\
\hline Rat liver & 0.03 & 1.10 & 0.67 & 44 \\
\hline Sea urchin (blastula) & 0.08 & 1.02 & 0.60 & 45 \\
\hline Sea urchin (gastrula) & 0.08 & 1.04 & 1.15 & 45 \\
\hline Pea bud & 0.05 & 1.10 & 0.41 & 46 \\
\hline S. cerevisiae & 0.11 & 1.17 & 0.50 & 47 \\
\hline N. crassa & 0.14 & 0.24 & 0.60 & 48 \\
\hline M. gypseum & 0.05 & 0.03 & 1.20 & 49 \\
\hline E. coli & \multicolumn{3}{|c|}{0.24} & 50 \\
\hline A. cylindrica & 0.05 & 0.02 & 0.07 & 51 \\
\hline G. cohnii* & 0.04 & 0.03 & 0.45 & Present study \\
\hline G. cohnii** & 0.03 & 0.02 & 0.27 & Present study \\
\hline P. trochoideum & 0.03 & 0.02 & 0.21 & Present study \\
\hline
\end{tabular}

* $2 \mathrm{M} \mathrm{NaCl}$ chromatin from log-phase cells

** $2 \mathrm{M} \mathrm{NaCl}$ chromatin from stationary-phase cells

observations that an increase in the level of nonhistone proteins is correlated with an increase in genetic activity $[23,41-43]$. There is also a marked increase in the amount of nonhistone protein in chromatin from the gastrula stage as compared to the blastula stage of sea urchin embryos (Table IV), which correlates with increased template activity.

\section{Dinoflagellate chromatin compared with other organisms}

Table IV shows the differences between the chemical composition of dinoflagellate chromatin and that of several eukaryotes. Although the acidinsoluble protein content is lower than typical eukaryotes, it is similar. The most striking difference is the amount of acid-soluble protein relative to DNA. This value is approximately one for higher plants and animals, and most of the acid-soluble protein is histone. In dinoflagellates, however, the acid-soluble protein/DNA ratio is only $0.02-0.08,12-50$ times lower than that of higher plants and animals. In fact, the dinoflagellates studied here have a protein content resembling that of the prokaryotes Escherichia coli [50] and Anabaena cylindrica [51]. Although there are several studies on bacterial chromatin, the example given in Table IV was chosen, because these investigators used more rigorous methods of preparing their chromatin than those used in other studies. Like the dinoflagellates, the chromatin from other eukaryotes, Mierosporum gypseum [49] and Allomyces arbuscula [52] is reported to have a very low acid-soluble protein/DNA ratio. By contrast, another fungus, the yeast Saccharomyces cervisiae [47] has a ratio of about 1 , like typical eukaryotes, while Neurospora crassa seems to be intermediate between these extremes. The data presented here clearly show that the acid-soluble protein content (and therefore also the histone content) of dinoflagellate chromatin is much lower than that of the typical eukaryotes; however, some other eukaryotes particularly the fungi may resemble the dinoflagellates. 


\section{Acknowledgements}

We thank Dr Robert Helling for use of the sonicator, Dr Leigh Towill for helpful discussions and Dr Sally Allen for help with the DNA melting experiments. This work was supported in part by an N.I.H. predoctoral fellowship (5 F01 GM 43747-02) to P.J.R.

\section{References}

1 Kubai, D.F. and Ris, H. (1970) Annu. Rev. Genet. 4, 263-294

2 DuPraw, E.J. (1970) DNA and Chromosomes pp. 103-117, Holt, Rinehart and Winston, New York

3 Ris, H. (1962) in The Interpretation of Ultrastructure (Harris, R.C.T., ed.), pp. 69-88, Academic Press, New York

4 Dodge, J. (1964) Arch. Mikrobiol. 48, 66-80

5 Rae, P.M.M. (1970) J. Cell Biol. 46, 106-113

6 Zingmark, R.G. (1970) Am. J. Bot. 57, 586-592

7 Soyer, M.O. (1971) Chromosoma 33, 70-114

8 Dodge, J. (1965) Excerpta Med. Int. Congr. Ser. 91,339

9 Dodge, J. (1966) in The Chromosomes of the Algae (Godward, M.B.E., ed.), pp. 96-115, Edward Arnold, New York

10 Kubai, D.F. and Ris, H. (1969) J. Cell Biol. 40, 508-528

11 Stewart, J.M. and Beck, J.S. (1967) J. Protozool. 14 (2), 225-231

12 Rizzo, P.J. and Noodén, L.D. (1972) Science 176, 796-797

13 Rizzo, P.J. and Noodén, L.D. (1973) J. Protozool. 20 (5), 666-672

14 Towill, L.E. and Noodén, L.D. (1973) Plant Cell Physiol. 14, 851-863

15 Frenster, J.H., Allfrey, V.G. and Mirsky, A.E. (1963) Proc. Natl. Acad. Sci. U.S. 50, 1026-1032

16 Hnilica, L. (1967) Prog. Nucl. Acid Res. Mol. Biol. 7, 25--106

17 Ogur, M. and Rosen, G. (1950) Arch. Biochem. Biophys. 25, 262-276

18 Burton, K. (1956) Biochem. J. 62, 315-322

19 Dische, F. (1955) in The Nucleic Acids (Chargaff, E. and Davidson, J., eds), Vol. 1, pp. 300-302, Academic Press, New York

20 Lowry, O.H., Rosebrough, J.N., Farr, A.L. and Randall, R.J, (1951) J. Biol. Chem. 193, 265-275

21 Marmur, J. (1961) J. Mol. Biol. 5, 109-118

22 Stern, H. (1967) in Methods in Enzymology (Grossman, L. and Moldave, K., eds), Vol. 12B, pp. 100--112, Academic Press, New York

23 Dingman, C.W. and Sporn, M.B. (1964) J. Biol. Chem. 239, 3483-3492

24 Shaw, L.M.J. and Huang, R.C.C. (1970) Biochemistry 9, 4530-4541

25 Spelsberg, T.C. and Hnilica, L.S. (1971) Biochim. Biophys. Acta 228, 202-211

26 Bhagavan, N.V. and Atchley, W.A. (1965) Biochemistry 4, 234-239

27 Busch, H. (1965) Histones and Other Nuclear Proteins, Academic Press, New York

28 Munro, H.N, and Fleck, A. (1966) in Methods of Biochemical Analysis (Glick, D., ed.), Vol. 14, pp. 113-176, Interscience, New York

29 Noodén, L.D. van den Broek, H.W.J, and Sevall, J.S. (1973) FEBS Lett. 29, 326-328

30 Bonner, J., Chalkley, G.R., Dahmus, M., Fambrough, D., Fujimura, F., Huang, R.C., Huberman, J., Jensen, R., Marushige, K., Ohlenbusch, H., Olivera, B. and Widholm, J. (1967) in Methods in Enzymology (Grossman, L, and Moldave, K., eds), Vol. 12B, pp. 3-65, Academic Press, New York

31 Franker, C.F. (1972) J. Phycol. 8, 264-268

32 Maggio, R., Siekevitz, P. and Palade, G.E. (1963) J. Cell Biol. 18, 293-312

33 Vendrely, R. and Vendrely, C. (1966) Protoplasm. Handb. Protoplasmaforsch. 5, 1-88

34 Zbarskii, I.B. and Georgiev, G.P. (1959) Biochim. Biophys. Acta 32, 301-302

35 Georgiev, G.P. and Chentsov, J.S. (1962) Exp. Cell Res. 27, 670-572

36 Molenaar, I., Sillevis-Smitt, W.W., Rozijn, Th.H. and Tonino, G.J.M. (1970) Exp. Cell Res. 60, 148156

37 Rizzo, P.J. and Noodén, L.D. (1974) Biochim. Biophys. Acta 349, 000-000

38 Bonitati, J., Elliott, W.G. and Miles, P.G. (1969) Anal. Biochem. 31, 339-404

39 de Deken-Grenson, M. and de Deken, R.H. (1959) Biochim. Biophys. Acta 31, 195-207

40 Fredericq, E. (1971) in Histones and Nucleohistones (Phillips, D.M.P., ed.), pp. 136-186. Plenum Press, London

41 Seligy, V. and Miyagi, M. (1969) Exp. Cell Res. 58, 27-34

42 Johnson, A.W. and Hnilica, L.S. (1970) Biochim. Biophys. Acta 224, 518-530

43 Kamiyama, M. and Wang, T.Y. (1971) Biochim. Biophys. Acta 228, 563-576 
44 van den Broek, H.W.J., Noodén, L.D. and Sevall, J.S. (1973) Biochemistry 12, 229-236

45 Hill, R.J., Poccia, D.L. and Doty, P. (1971) J. Mol. Biol. 61, 445-462

46 Elgin, S.C.R. and Bonner, J. (1970) Biochemistry 9, 4440--4447

47 van der Vliet, P.C., Tonino, G.J.M. and R.ozijn, Th.H. (1969) Biochim. Biophys. Acta $195,473-483$

48 Hsiang, M.W. and Cole, R.D. (1973) J. Biol. Chem. 248, 2007-2013

49 Leighton, T.J., Dill, B.C., Stock, J.J. and Phillips, C. (1971) Proc. Natl. Acad. Sci. U.S. 68, 677-680

50 Kadoya, M., Mitsui, H. and Takagi, Y. (1964) Biochim. Biophys. Acta 91, 36-45

51 Makino, F. and Tsuzuki, J (1971) Nature 231, 446-447

52 Stumm, C. and van Went, J.L. (1968) Experientia 24, 1112-1113 